\title{
Role of Various Extractants in Removing Group-IIB Elements of Soils Incubated with EDTA
}

\author{
Tanmoy Karak ${ }^{1, \star}$, Uttam Kumar Singh ${ }^{1}$, and D.K. Das ${ }^{2}$ \\ ${ }^{1}$ Department of Soil and Water Sciences, College of Resources and Environmental \\ Sciences, China Agricultural University, Beijing-100094, P.R. China; ${ }^{2}$ Department \\ of Agricultural Chemistry and Soil Science, Faculty of Agriculture, Bidhan Chandra \\ Krishi Viswavidyalaya, Mohanpur, Nadia-741252, West Bengal, India

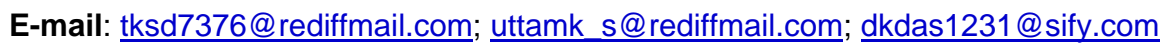

Received October 1, 2004; Revised November 30, 2004; Accepted November 30, 2004; Published December 6, 2004

This paper presents the results of an experimental investigation undertaken to evaluate different extractant solutions viz. $\mathrm{HCl}, \mathrm{Mg}\left(\mathrm{NO}_{3}\right)_{2}$, and DTPA with the range of concentration from 0.001 to $0.1 \mathrm{~N}$ after incubation with group-IIB metals ( $\mathrm{Zn}, \mathrm{Cd}$, and $\mathrm{Hg}$ ) and EDTA to understand the capability to remove $\mathrm{Zn}, \mathrm{Cd}$, and $\mathrm{Hg}$ from soils. Two noncontaminated soils, one acidic (GHL) and the other alkaline (KAP), in reaction were taken from an agricultural field of West Bengal, India for this investigation. Experiments were conducted on these two soils spiked with $\mathrm{Zn}^{\prime \prime}, \mathrm{Cd}^{\prime \prime}$, and $\mathrm{Hg}^{\prime \prime}$ in concentrations of 612, 321, and $215 \mathrm{mg} / \mathrm{kg}$ for soil GHL and 778,298 , and $157 \mathrm{mg} / \mathrm{kg}$ for soil KAP, respectively, which simulate typical electroplating waste contamination. The removal of $\mathrm{Zn}, \mathrm{Cd}$, and $\mathrm{Hg}$ in soil $\mathrm{GHL}$ within the range of $\mathrm{HCl}$ concentrations was 8.2-16.5, 12.2-19.1, and 4.3-6.9 whereas these were 6.5-7.6, 8.5-14.1, and 3.2-5.2 in soil KAP. The removal of $\mathrm{Zn}, \mathrm{Cd}$, and $\mathrm{Hg}$ in soil $\mathrm{GHL}$ within the range of $\mathrm{Mg}\left(\mathrm{NO}_{3}\right)_{2}$ concentrations were 12.2-28.5, 19.1-24.6, and 18.2-19.1 whereas these were 9.112.1, 8.3-12.1, and 10.6-48.1 in soil KAP. For DTPA extractant, the percent removal of metal was found to be significantly higher than the other two extractants, which corroborates that DTPA is a better extractant for soil cleaning.

KEYWORDS: Gr-IIB elements ( $\mathrm{Zn}, \mathrm{Cd}$, and $\mathrm{Hg}$ ), extractants, EDTA (ethylenediaminetetraacetic acid), DTPA (diethylenetriaminepentaacetic acid), $\mathrm{HCl}, \mathrm{Mg}\left(\mathrm{NO}_{3}\right)_{2}$

DOMAINS: soil systems, heavy metals in the environment

\section{INTRODUCTION}

Zn, Cd, and Hg are present in group-IIB of the Periodic Table of which Zn is an essential micronutrient[1], but the other two have no beneficial effect for animals or plants. However, according to the USEPA[2], Zn is also a major public health concern at many contaminated sites. Although $\mathrm{Zn}$ is an essential micronutrient, all the elements present in group-IIB are referred to as heavy metals. Heavy metals are conventionally defined as elements with metallic properties (ductility, conductivity, stability as cations, ligand specificity, etc.) and an atomic number $>20$ [3]. It is a remarkable contrast that, at one place, $\mathrm{Zn}$ is biologically one of the most 
important metals and is apparently necessary to all forms of life[4] and at another, Cd and $\mathrm{Hg}$ have no known biological role and are amongst the most toxic elements. All these metals are natural components of soil. Soil contamination resulting from improper waste disposal practices is a major concern.

Contamination, however, has resulted from industrial activities such as mining and smelting of metalliferous ores, electroplating, gas exhaust, energy and fuel production, fertilizer and pesticide application, and generation of municipal waste[5]. High levels of metals in soil can be phytotoxic. Poor plant growth and soil cover caused by metal toxicity can lead to metal mobilization in runoff water and subsequent deposition into nearby bodies of water.

$\mathrm{Zn}$ is readily adsorbed by clay minerals, carbonates, or hydrous oxides. Precipitation is not a major mechanism of retention of $\mathrm{Zn}$ in soils because of the relatively high solubility of $\mathrm{Zn}$ compounds. Cd may be adsorbed by clay minerals, carbonates, or hydrous oxides of Fe and Mn or may be precipitated as cadmium carbonate, hydroxide, and phosphate. Evidence suggests that adsorption mechanisms may be the primary source of Cd removal from soils[6]. Hg is introduced into the environment by both natural and anthropogenic processes, and, because of its volatility and solubility, is efficiently dispersed throughout the biosphere[7]. It is an environmental pollutant of concern not because of its direct impact on aquatic organisms, but because of their consumption by humans and other fish-eating mammals and birds.

Soil washing is the most commonly used treatment technology for the remediation of metal-contaminated soils[2]. This technique is an ex situ treatment method and is less expensive than many traditional or innovative treatment technologies, especially when smaller soil volumes are to be treated[2]. In this method, the contaminated soil is excavated and mixed with an extractant solution. The extractant solution may be water, acid, oxidizing agent, chelating agent, or surfactant, depending on the type of contaminant. The soil and the extractant solution are mixed thoroughly for a specified time, and the soil is dewatered to separate the soil and liquids. The resulting soil that meets regulatory requirements can be backfilled at the excavated site. The liquids that contain contaminants are further processed using conventional wastewater treatment technologies to recover the contaminants[2].

The environmental fate of chelating agents has received considerable attention. EDTA (ethylenediaminetetraacetic acid), for example, occurs at a higher concentration in river water than any other identified organic compound[8]. EDTA has been used as a chelating agent in the past to decontaminate nuclear reactors[9]. In agriculture, EDTA complexes have been used for about 30 years as commercial soil amendments to improve micronutrient availability. EDTA is a powerful hexadentate chelating ligand as metal carried in soils depends on their ability to keep these metals in soluble and mobile forms. To achieve this, the EDTA ligand must remain in solution and continue to complex with the metal ion present in soils. Attempts have been made to develop theoretical models from which the complexation of heavy metals by various chelates can be predicted and explained[10].

EDTA is persistent in the environment because it is resistant to decomposition by radiation[11] and rather slowly biodegradable in soil[12]. Bolton et al.[12] showed that only 15\% of EDTA added to soil was degraded after 5 months, indicating that it could affect metals for a significant period of time. They also found that EDTA was not mineralized more rapidly or to a great extent in the surface soil than in the subsurface sediments. These results contrast with previous studies in which surface soils and organic C-enriched soils had greater rates and amounts of EDTA[13].

It is likely that chelate structure and/or the liability of the metal-chelate complex determine the resistance of the complex to mineralization. Diethylenetriaminepentaacetic acid (DTPA) and $0.1 N \mathrm{HCl}$ extraction procedures are commonly employed to estimate the plant-available forms of micronutrients in soil. They are used equally to determine available forms of heavy metals such as $\mathrm{Cd}$ and $\mathrm{Hg}[14] .1 M \mathrm{Mg}\left(\mathrm{NO}_{3}\right)_{2}$ was chosen as an extractant because this solution extracts the most labile form of metals in soil without disturbing other fractions[15]. The presence of EDTA in soil may alter the mobility and transport of $\mathrm{Zn}, \mathrm{Cd}$, and $\mathrm{Hg}$ in soils because of the formation of water-soluble chelates, thus increasing the potential for metal pollution of natural waters. Mobility of metals is related to their extractability.

The aim of the experiment described here was to study the influence of EDTA on the extractability of Zn, $\mathrm{Cd}$, and $\mathrm{Hg}$ by using $\mathrm{HCl}, \mathrm{Mg}\left(\mathrm{NO}_{3}\right)_{2}$, and DTPA in both metal-amended soils. These studies provided valuable information on the distribution of $\mathrm{Zn}, \mathrm{Cd}$, and $\mathrm{Hg}$ in two soils of West Bengal, India and the removal 
of these metals using $\mathrm{HCl}, \mathrm{Mg}\left(\mathrm{NO}_{3}\right)_{2}$, and DTPA after EDTA treatment. The present study was aimed to investigate the removal of $\mathrm{Zn}, \mathrm{Cd}$, and $\mathrm{Hg}$ from two diverse soils by using the above-mentioned extractant at different concentrations in order to determine an effective washing solution for the remediation of metalcontaminated soils.

\section{MATERIALS AND METHODS}

\section{Soils}

Topsoils were taken from two different agricultural fields of West Bengal, India that were previously used for cultivation of rice. Soil samples were collected from the Ap horizon $(0-20 \mathrm{~cm})$. The samples were processed, passed through a 2-mm sieve, and analyzed for physical and chemical properties (Table 1) such as pH, organic $\mathrm{C}$, clay, and $\mathrm{CaCO}_{3}$ using standard analytical methods[16]. Cation exchange capacity (CEC) was calculated by the summation of exchangeable acidity and bases as proposed by Hendershot and Duquette[17]. Concentrations of plant-available $\mathrm{Zn}, \mathrm{Cd}$, and $\mathrm{Hg}$ in soil samples were determined using the DTPA method[18] and the total amounts of $\mathrm{Zn}, \mathrm{Cd}$, and $\mathrm{Hg}$ were estimated using the procedure described by Kuo et al.[19].

TABLE 1

Physical and Chemical Properties of the Experimental Soils

\begin{tabular}{|c|c|c|c|}
\hline \multirow{2}{*}{\multicolumn{2}{|c|}{ Properties }} & \multicolumn{2}{|c|}{ Soil } \\
\hline & & \multirow{2}{*}{$\begin{array}{c}\text { Ghatal (GHL) } \\
5.6\end{array}$} & \multirow{2}{*}{$\begin{array}{c}\text { Kakdwip (KAP) } \\
8.1\end{array}$} \\
\hline $\mathrm{pH}(1: 2.5)$ & & & \\
\hline Organic C, g/kg & & 5.2 & 1.6 \\
\hline Clay, g/kg & & 284 & 66 \\
\hline Textural class & & Silty clay loam & Silty loam \\
\hline Taxonomic classific & & Typic Paleustalf & Typic Haplaquept \\
\hline $\mathrm{CEC}\left[\mathrm{cmol}\left(\mathrm{p}^{+}\right) / \mathrm{kg}\right]$ & & 36.5 & 8.0 \\
\hline $\mathrm{CaCO}_{3}(\%)$ & & 0.42 & 5.91 \\
\hline \multirow[t]{3}{*}{ DTPA, mg/kg } & $\mathrm{Zn}$ & 0.56 & 0.08 \\
\hline & $\mathrm{Cd}$ & $\mathrm{ND}^{\dagger}$ & ND \\
\hline & $\mathrm{Hg}$ & ND & ND \\
\hline \multirow[t]{3}{*}{ Total metal, mg/kg } & $\mathrm{Zn}$ & 1.25 & 2.53 \\
\hline & $\mathrm{Cd}$ & 0.18 & 0.13 \\
\hline & $\mathrm{Hg}$ & 0.08 & 0.02 \\
\hline
\end{tabular}

${ }^{\dagger} \mathrm{ND}$, not detectable.

\section{Contaminants}

The soils were spiked with $\mathrm{Zn}, \mathrm{Cd}$, and $\mathrm{Hg}$ to simulate typical electroplating waste constituents. The metals were applied in the form of $\mathrm{Zn}\left(\mathrm{NO}_{3}\right)_{2} \cdot 6 \mathrm{H}_{2} \mathrm{O}$ for $\mathrm{Zn}$, $\mathrm{Cd}\left(\mathrm{NO}_{3}\right)_{2} \cdot 4 \mathrm{H}_{2} \mathrm{O}$ for $\mathrm{Cd}$, and $\mathrm{Hg}\left(\mathrm{NO}_{3}\right)_{2} \cdot \mathrm{H}_{2} \mathrm{O}$ for $\mathrm{Hg}$ on both soils. The soils were spiked by adding these chemicals dissolved in deionized water to the air-dried soils. The soils were equilibrated for 2 months and the resulting moisture content was $45 \%$ for these two experimental soils. After the preparation of the contaminant-spiked soils, they were mixed with $\mathrm{Na}_{2}$ EDTA solution at the rate of $0.2 \mathrm{mg} / \mathrm{kg}$ soil to $300 \mathrm{~g}$ of soil samples. After being mixed well, each sample was split into three 100-g replications and put into plastic pots. The pots were placed in the greenhouse and the water content of the soil 
was adjusted to $70 \%$ of field capacity. In all treatments, $\mathrm{pH}$ was adjusted to soil-native $\mathrm{pH}$ by adding $\mathrm{NaOH}$ or $\mathrm{HNO}_{3}$. Throughout the 6 months, water losses exceeding $10 \%$ of the initial values were compensated for by addition of distilled water.

\section{Soil Extractant and Extractant Procedure}

Six months after the treatments, the soils were air dried, ground, and sieved through a 2-mm sieve. Total amounts of $\mathrm{Zn}, \mathrm{Cd}$, and $\mathrm{Hg}$ in simulated soils were estimated using $\mathrm{HNO}_{3}-\mathrm{HCIO}_{4}$ [19] (Table 2). The simulated soil samples were extracted for $\mathrm{Zn}, \mathrm{Cd}$, and $\mathrm{Hg}$ using different extractants viz. $\mathrm{HCl}$, DTPA, and $\mathrm{Mg}\left(\mathrm{NO}_{3}\right)_{2}$. Three different concentrations $(1 N, 0.1 N$, and $0.01 N)$ of $\mathrm{HCl}, \mathrm{Mg}\left(\mathrm{NO}_{3}\right)_{2}$, and DTPA were used as extractant. Extraction was performed with a liquid to solids ratio (L/S) of 10:1. The mixture was stirred constantly for $2 \mathrm{~h}$ using a temperature-control orbital shaker. The 2-h mixing time was selected to investigate the easily removable $\mathrm{Zn}, \mathrm{Cd}$, and $\mathrm{Hg}$ fractions and to compare the relative removal efficiencies by various extractants. The soil solids were separated by centrifuging at $3000 \mathrm{rpm}$ for $15 \mathrm{~min}$ and filtrated using a Whatman No.42 filter paper. The filtrate was analyzed for Zn, Cd, and Hg by atomic absorption spectrophotometry. Two of the three replicates were analyzed. If the data of two replicates were not within an acceptable range of precision (relative error $<5 \%$ for high concentrations and $<15 \%$ for low concentrations), the third sample was analyzed. This was necessary when the analyte was near the detection limit of the analytical procedure. Lastly, the removal of each contaminant was calculated using the following equation:

$$
\text { Contaminant Removal }(\%)=\frac{\text { Contaminant Mass in Filtrate }\left(C_{L} V_{L}\right)}{\text { Initial Contaminant Mass in Soil }\left(C_{S} M_{S}\right)} \times 100
$$

where $C_{L}$ and $C_{S}$ are the concentrations of contaminant filtrate $(\mathrm{mg} / \mathrm{l})$ and soil $(\mathrm{mg} / \mathrm{kg})$, respectively. $V_{L}$ is the volume of supernatant (L) and $M_{s}$ is the dry mass of the soil (kg).

TABLE 2

Total Amount of Zn, Cd, and $\mathrm{Hg}(\mathrm{mg} / \mathrm{kg})$ Present

in Contaminant-Spiked Soil

\begin{tabular}{llll}
\hline Soil & Zn & Cd & Hg \\
\hline GHL & 612 & 321 & 215 \\
KAP & 778 & 298 & 157 \\
\hline
\end{tabular}

\section{RESULTS AND DISCUSSION}

\section{Extraction Using $\mathrm{HCl}$}

Table 3 shows the metal removals from both acidic (GHL) and alkaline (KAP) soils. In both soils, the percentage of metal removed increases with an increase of acid strength, however, these percentages of removal of metal were lower in alkaline soil. In GHL, Zn, Cd, and $\mathrm{Hg}$ removal ranged from 8.2-16.5, 12.219.1, and 4.3-6.9\%, respectively. Whereas these were 6.5-7.6, 8.5-14.1, and 3.2-5.2\% for Zn, Cd, and $\mathrm{Hg}$ in KAP soil, respectively. Thus, use of $\mathrm{HCl}$ decreases the removal percentage of group-IIB elements when one moves from top to bottom in the group except for $\mathrm{Cd}$. This can be attributed to the significant covalent character of metal chloride, their comparatively low melting point, and by their layer-lattice (2D) crystal structures. In all cases, these may be regarded as close-packed lattices of chloride ions in which the $\mathrm{Zn}^{\mathrm{II}}$ ions occupy tetrahedral, $\mathrm{Cd}^{\mathrm{II}}$ ion octahedral, and $\mathrm{Hg}^{\mathrm{II}}$ ion elongated octahedral site. The structure of $\mathrm{CdCl}_{2}$ is also important since it is typical of $\mathrm{MX}_{2}$ (where $\mathrm{X}=\mathrm{F}, \mathrm{Cl}, \mathrm{Br}$, or I) compound and its marked polarization effects 
are expected[20]. In both the soils, the removal percentage of group-IIB metal follows $\mathrm{Cd}>\mathrm{Zn}>\mathrm{Hg}$. The lower percentage of $\mathrm{Hg}$ removal can be explained by the fact that the covalency is still more pronounced in $\mathrm{HgCl}_{2}$ than in the corresponding chlorides of $\mathrm{Zn}$ and $\mathrm{Cd}$. The crystalline structure of $\mathrm{HgCl}_{2}$ is also an important factor for its solubility in any solvent medium[21]. The crystalline structure of $\mathrm{HgCl}_{2}$ is comprised of linear $\mathrm{Cl}-\mathrm{Hg} . . . \mathrm{Cl}$ molecules in which radii of $\mathrm{Cl}-\mathrm{Hg}$ is $225 \mathrm{pm}$ and the next shortest $\mathrm{Hg}$....Cl distance is $334 \mathrm{pm}$ [21]. Therefore, structure and covalence of group-IIB metal chloride is an important factor in their removal by $\mathrm{HCl}$ extractant.

TABLE 3

Removal of Zn, Cd, and $\mathrm{Hg}(\%)$ from Contaminated-Spiked Soils Using $\mathrm{HCl}$

\begin{tabular}{ccccc}
\hline \multirow{2}{*}{ Soil } & Contaminant & \multicolumn{3}{c}{ Strength of HCl } \\
\cline { 3 - 5 } & & $\mathbf{0 . 0 0 1 N}$ & $\mathbf{0 . 0 1 N}$ & $\mathbf{1 N}$ \\
\hline GHL & $\mathrm{Zn}$ & 8.2 & 10.1 & 16.5 \\
& $\mathrm{Cd}$ & 12.2 & 18.9 & 19.1 \\
& $\mathrm{Hg}$ & 4.3 & 5.2 & 6.9 \\
$\mathrm{KAP}$ & $\mathrm{Zn}$ & 6.5 & 6.9 & 7.6 \\
& $\mathrm{Cd}$ & 8.5 & 12.3 & 14.1 \\
& $\mathrm{Hg}$ & 3.2 & 4.8 & 5.2 \\
\hline
\end{tabular}

\section{Extraction Using $\mathrm{Mg}\left(\mathrm{NO}_{3}\right)_{2}$}

Table 4 summarizes the metal removal efficiencies of $\mathrm{Mg}\left(\mathrm{NO}_{3}\right)_{2}$ from the soils at different concentrations. For soil GHL, the percentages of $\mathrm{Zn}$ and $\mathrm{Cd}$ removed was found maximum when $0.01 \mathrm{~N} \mathrm{Mg}\left(\mathrm{NO}_{3}\right)_{2}$ was applied as an extractant and they were 28.5 and $24.6 \%$, respectively. In the case of $\mathrm{Hg}$, the amount of $\mathrm{Hg}$ removed increases with an increase of extractant strength in both soils. However, the percentage of Hg removed from soil KAP was found to be significantly higher than GHL. For soil KAP, the percentages of removed Zn and Cd decrease with an increase of extractant strength. It should be noted that extractability of $\mathrm{Mg}\left(\mathrm{NO}_{3}\right)_{2}$ is higher than $\mathrm{HCl}$. Table 4 shows that $\mathrm{Mg}\left(\mathrm{NO}_{3}\right)_{2}$ has a strong capability to extract $\mathrm{Hg}$ in alkaline soil. The nitrate group $\left(-\mathrm{NO}_{3}\right)$ is a versatile ligand and numerous modes of coordination have been found in nitrato complexes[22]. When more sites become available, or when the coligands are less bulky, then the nitrate group become bidentate bridging, which forms a more extensive network of bridging nitrate group[20]. This might be the reason for the removal of a high percentage of $\mathrm{Zn}, \mathrm{Cd}$, and $\mathrm{Hg}$ at $0.01 \mathrm{~N} \mathrm{Mg}\left(\mathrm{NO}_{3}\right)_{2}$ in soil GHL.

TABLE 4

Removal of Zn, Cd, and $\mathrm{Hg}(\%)$ from Contaminated-Spiked Soils Using $\mathrm{Mg}\left(\mathrm{NO}_{3}\right)_{2}$

\begin{tabular}{ccccc}
\hline \multirow{3}{*}{ Soil } & Contaminant & \multicolumn{3}{c}{ Strength of $\mathbf{M g}\left(\mathrm{NO}_{\mathbf{3}}\right)_{\mathbf{2}}$} \\
\cline { 3 - 5 } & & $\mathbf{0 . 0 0 1} \boldsymbol{N}$ & $\mathbf{0 . 0 1 N}$ & $\mathbf{1 N}$ \\
\hline $\mathrm{GHL}$ & $\mathrm{Zn}$ & 14.1 & 28.5 & 12.2 \\
& $\mathrm{Cd}$ & 19.1 & 24.6 & 23.1 \\
& $\mathrm{Hg}$ & 18.2 & 18.9 & 19.1 \\
$\mathrm{KAP}$ & $\mathrm{Zn}$ & 12.1 & 9.8 & 9.1 \\
& $\mathrm{Cd}$ & 12.1 & 8.5 & 8.3 \\
& $\mathrm{Hg}$ & 10.6 & 18.9 & 48.1 \\
\hline
\end{tabular}


TABLE 5

Removal of $\mathrm{Zn}, \mathrm{Cd}$, and $\mathrm{Hg}(\%)$ from Contaminated-Spiked Soils Using DTPA

\begin{tabular}{lcccc}
\hline \multirow{2}{*}{ Soil } & Contaminant & \multicolumn{3}{c}{ Strength of DTPA } \\
\cline { 3 - 5 } & & $\mathbf{0 . 0 0 1 N}$ & $\mathbf{0 . 0 1 N}$ & $\mathbf{1 N}$ \\
\hline $\mathrm{GHL}$ & $\mathrm{Zn}$ & 35 & 49 & 64 \\
& $\mathrm{Cd}$ & 32 & 47 & 62 \\
& $\mathrm{Hg}$ & 48 & 72 & 81 \\
$\mathrm{KAP}$ & $\mathrm{Zn}$ & 39 & 59 & 71 \\
& $\mathrm{Cd}$ & 39 & 52 & 67 \\
& $\mathrm{Hg}$ & 51 & 78 & 89 \\
\hline
\end{tabular}

\section{Extraction Using DTPA}

Table 5 shows the metal removal from both soils using DTPA at different concentrations. Chelating agents modify metal concentrations in soil solution by forming various soluble complexes, thus enhancing metal removal[23]. In both soils, the percentage of metal removal increases with an increase of DTPA concentrations, however, the percentage of metal removed from KAP soil was higher than GHL soil. The percentages Zn, Cd, and Hg in soil GHL ranged from 35-64, 32-62, and 48-81 whereas these were 39-71, 39-67, and 51- 89 in soil KAP. The Zn, Cd, and Hg removal increases significantly using DTPA when compared with the use of $\mathrm{HCl}$ or $\mathrm{Mg}\left(\mathrm{NO}_{3}\right)_{2}$ as extractants. This may be due to the fact that these metals form more stable complexes with DTPA and more solubilized M-DTPA. The soils were contaminated with $\mathrm{Zn}, \mathrm{Cd}$, and $\mathrm{Hg}$ followed by incubation with EDTA. The log stability constants of M-EDTA and DTPA complexes (M $=\mathrm{Zn}, \mathrm{Cd}$, and Hg) are shown in Table 6 . From Table 6 it is confirmed that the stability of EDTA and DTPA complexes follows the sequence $\mathrm{Hg}>\mathrm{Zn}>\mathrm{Cd}$. After addition of DTPA, M-EDTA complexes shift to MDTPA complexes as M-DTPA complexes are more stable than M-EDTA. As the conditions become progressively more alkaline in soil KAP, $\mathrm{H}^{+}$ions begin to dissociate from the DTPA molecule's five carboxyl groups, eventually leaving seven pairs of electrons (five pairs from the carboxyl groups and two nitrogen pairs) that are available for bonding with a metal cation. At high $\mathrm{pH}$, soil KAP bears negative charge and metal-DTPA complex also bears the same charge, which increases the possibilities of the migration of metalDTPA complexes from soil-to-soil solution. Another reason to favor M-DTPA complex formation is that DTPA is a stronger chelating agent than that of

TABLE 6

Stability Constants $\left(\log K_{0.1}^{c}\right)$ at $25^{\circ} \mathrm{C}$ for Group-IIB

Metal-EDTA and DTPA Reactions[24]

\begin{tabular}{lcc}
\hline \multirow{2}{*}{ Reaction } & \multicolumn{2}{c}{ Ligand (L) } \\
\cline { 2 - 3 } & EDTA & DTPA \\
\hline $\mathrm{Zn}+\mathrm{L} \leftrightarrow \mathrm{ZnL}$ & 16.44 & 18.29 \\
$\mathrm{Zn}+\mathrm{H}+\mathrm{L} \leftrightarrow \mathrm{ZnHL}$ & 19.44 & 23.89 \\
$\mathrm{Cd}+\mathrm{L} \leftrightarrow \mathrm{CdL}$ & 16.36 & 19.00 \\
$\mathrm{Cd}+\mathrm{H}+\mathrm{L} \leftrightarrow \mathrm{CdHL}$ & 19.26 & 23.17 \\
$\mathrm{Hg}+\mathrm{L} \leftrightarrow \mathrm{HgL}$ & 21.50 & 26.40 \\
$\mathrm{Hg}+\mathrm{H}+\mathrm{L} \leftrightarrow \mathrm{HgHL}$ & 24.60 & 30.68 \\
\hline
\end{tabular}


EDTA. DTPA forms complexes with metal ions most efficiently in basic solutions[25]. The degree of complexation depends on the $\mathrm{pH}$ of the aqueous system. At low $\mathrm{pH}$ values, the DTPA exists in the acid form or positive charge species and does not chelate effectively because hydrogen ions occupy the coordinating functional groups. As the $\mathrm{pH}$ is increased, the DTPA reaches a maximum chelating ability as DTPA becomes fully deprotonated because of negative charge generation as carboxylate ion, $-\mathrm{COO}^{-}$, from carboxylic acid group, which corroborates that the removal of metal from KAP is always in higher than GHL by DTPA. The covalent radii of Zn, Cd, and Hg are 131, 148, and 149 pm, respectively[26]. Therefore, soft character increases from Zn to Hg. According to the hard/soft acid base principle, hard acids prefer to associate with hard bases, and soft acids prefer soft bases[27]. The almost invariable oxidation state of $\mathrm{Zn}$ and $\mathrm{Cd}$ is +2 and in aqueous solution they are appreciably hydrolyzed to species such as $\left[\mathrm{M}(\mathrm{OH})\left(\mathrm{H}_{2} \mathrm{O}\right)_{\mathrm{x}}\right]^{+}$and $\left[\mathrm{M}_{2}(\mathrm{OH})\left(\mathrm{H}_{2} \mathrm{O}\right)_{\mathrm{x}}\right]^{3+}$ and a number of basic salts such as $\mathrm{ZnCO}_{3} \cdot 2 \mathrm{Zn}(\mathrm{OH})_{2} \cdot \mathrm{H}_{2} \mathrm{O}$ and $\mathrm{CdCl}_{2} .4 \mathrm{Cd}(\mathrm{OH})_{2}$ can be precipitated. But in contrast, $\mathrm{Zn}^{\mathrm{II}}$ and $\mathrm{Cd}^{\mathrm{II}}$ compounds hydrolyze rapidly in water, no doubt because of the ability of $\mathrm{Zn}^{\mathrm{II}}$ and $\mathrm{Cd}^{\mathrm{II}}$ to increase their coordination number above 4 and form DTPA complexes. However, in the case of $\mathrm{Hg}$, the ability to form DTPA complex is much more pronounced because of its characteristic ability to form not only conventional ammine and amine complexes, but also the predominant chelate effect[20]. Overall, these results show that the formation of soluble M-DTPA complexes in KAP at soil-native $\mathrm{pH}$ may provide improved removal efficiency of metal in the presence of multiple metals, and the effects of soil $\mathrm{pH}$ at high concentrations of DTPA on metal removal require further investigation.

The results of the Pearson correlation (Table 7) of three extractants showed that DTPA-HCl and DTPA$\mathrm{Mg}\left(\mathrm{NO}_{3}\right)_{2}$ show the significant correlation in both soils for all metal removal. However, there were no significant correlations between $\mathrm{HCl}$ and $\mathrm{Mg}\left(\mathrm{NO}_{3}\right)_{2}$ extractants for $\mathrm{Zn}$ and $\mathrm{Hg}$ in soils GHL.

TABLE 7

Pearson Correlation Coefficients Between Extractant Methods for Metals

\begin{tabular}{lcccccc}
\hline & \multicolumn{3}{c}{ GHL } & \multicolumn{3}{c}{ KAP } \\
\cline { 2 - 7 } & Zn & Cd & Hg & Zn & Cd & Hg \\
\hline DTPA-HCl & $0.981^{*}$ & $0.996^{*}$ & 0.989 & $0.981^{*}$ & $0.919^{\star}$ & $0.966^{*}$ \\
DTPA-Mg(NO $\left.{ }_{3}\right)_{2}$ & $0.991^{*}$ & $0.892^{*}$ & $0.899^{\star}$ & $0.956^{*}$ & $0.798^{\star}$ & $0.874^{*}$ \\
$\mathrm{HCl}-\mathrm{Mg}\left(\mathrm{NO}_{3}\right)_{2}$ & $0.216^{\mathrm{NS}}$ & $0.699^{*}$ & $0.213^{\mathrm{NS}}$ & $0.869^{\star}$ & $0.925^{\star}$ & $0.925^{*}$ \\
\hline
\end{tabular}

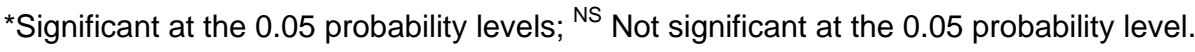

\section{CONCLUSIONS}

This experiment exhibits that the overall removal of Zn, Cd, and Hg was higher when DTPA was used as the extractant as compared to the other extractants, $\mathrm{HCl}$ and $\mathrm{Mg}\left(\mathrm{NO}_{3}\right)_{2}$. From this experiment, it can be said that removal of $\mathrm{Zn}, \mathrm{Cd}$, and $\mathrm{Hg}$ from the soils should be an important consideration in designing a soil-washing system. $\mathrm{HCl}$ and $\mathrm{Mg}\left(\mathrm{NO}_{3}\right)_{2}$ were not as effective in removing $\mathrm{Zn}, \mathrm{Cd}$, and $\mathrm{Hg}$ as DTPA, but $\mathrm{Mg}\left(\mathrm{NO}_{3}\right)_{2}$ was found to be more effective than $\mathrm{HCl}$ to remove these metals from soils. Besides, this study showed that complete removal of $\mathrm{Zn}, \mathrm{Cd}$, and $\mathrm{Hg}$ from these two soils is difficult when trying to achieve a complete soilwashing process. Additionally, the use of one extractant may not be effective in removing all the metals from the soils, therefore, a sequence of extractants may be needed for the removal of multiple metals of group-IIB contaminants from soils. 


\section{REFERENCES}

1. Das, D.K. (2000) In Micronutrients: Their Behaviour in Soils and Plants. Kalyani Publishers, Ludhiana, India.

2. United States Environmental Protection Agency (1995) Contaminants and Remedial Options at Selected MetalContaminated Sites. EPA/540/R-95/512. Office of Research and Development, Washington, D.C.

3. $\quad$ Hale, W.G. and Margham, J.P. (1988) Collins Dictionary of Biology. Collins, Glasgow.

4. Prince, R.H. (1979) Some aspects of the bioinorganic chemistry of zinc. Adv. Inorg. Chem. Radiochem. 22, 349-440.

5. Kabata-Pendias, A. and Pendias, H. (1989) Trace Elements in the Soil and Plants. CRC Press, Boca Raton, FL.

6. Dudley, L.M., McLean, J.E., Furst, T.H., and Jurinak, J.J. (1991) Sorption of Cd and Cu from an acid mine waste extract by two calcareous soils: column studies. Soil Sci. 151, 121-135.

7. Mason, R.P. and Lawrence, A.L. (1999) Concentration, distribution, and bioavailability of mercury and methylmercury in sediment of Baltimore Harbor and Chesapeake Bay, Maryland, USA. Environ. Toxicol. Chem. 18, 2438-2447.

8. Nowack, B. (2002) Environmental chemistry of aminopolycarboxylate chelating agents. Environ. Sci. Technol. 36, 4009-4016.

9. $\quad$ Ayers, J.A. (1970) Decontamination of Nuclear Reactors and Equipment. The Ronald Press Company, New York.

10. Lindsay, W.L. (1979) Chelate equilibria. In Chemical Equilibria in Soils. John Wiley \& Sons, New York. pp. 238263.

11. Kari, F.G. and Giger, W. (1995) Modeling the photochemical degradation of ethylenediaminetetraacetate in the river Glatt. Environ. Sci. Technol. 29, 2814-2827.

12. Bolton, H., Li, S.W., Workmen, D.J., and Girvin, D.C. (1993) Biodegradation of synthetic chelates in subsurface sediments from the southeast coastal plain. J. Environ. Qual. 22, 125-132.

13. Tiedje, J.M. (1977) Influence of environmental parameters on EDTA biodegradation in soils and sediments. $J$. Environ. Qual. 6, 21-26.

14. Roca, J. and Pomares, F. (1991) Prediction of available heavy metals by six chemical extradants in a sewage-sludge amended soil. Commun. Soil Sci. Plant Anal. 22, 2119-2136.

15. Shuman, L.M. (1985) Fractionation method for soil microelements. Soil Sci. 140, 11-23.

16. Page, A.L., Ed. (1982) Methods of Soil Analysis, Part 2. Chemical and Microbiological Properties. Soil Science Society of America, Madison, WI.

17. Hendershot, W.H. and Duquette, M. (1986) A simple barium chloride method for determining cation exchange capacity and exchangeable cations. Soil Sci. Soc. Am. J. 50, 605-608.

18. Lindsay, W.L. and Norvell, W.A. (1978) Development of a DTPA soil test for zinc, iron, manganese, and copper. Soil Sci. Soc. Am. J. 42, 421-428.

19. Kuo, S., Heilman, P.E., and Baker, A.S. (1983) Distribution and forms of copper, zinc, cadmium, iron, and manganese in soils near a copper smelter. Soil Sci. 135, 101-109.

20. Greenwood, N.N. and Earnshaw, A. (1984) Chemistry of the Elements. Pergamon Press, Oxford.

21. Grdenic, D. (1965) The structural chemistry of mercury. Q. Rev. 19, 303-328.

22. Addison, C.C., Logan, N., Wallwork, S.C., and Garner, C.D. (1971) Structural aspects of coordinated nitrate groups. Q. Rev. 25, 289-322.

23. Reddy, K.R. and Chinthamreddy, S. (2000) Comparison of different extractants for removing heavy metals from contaminated clayey soils. J. Soil Sediment Contamin. 9, 449-462.

24. Martell, A.L. and Smith, R.M. (1974) Critical Stability Constant. Vol I. Amino Acids. Plenum Press, New York.

25. Fredd, C.N. and Fogler, H.S. (1998) The influence of chelating agents on the kinetics of calcite dissolution. J. Colloid Interface Sci. 204, 187-197.

26. Sanderson, R.T. (1962) In Chemical Periodicity. Reinhold, New York.

27. Pearson, R.G. (1995) The HSAB Principle - More Quantitative Aspects. Inorg. Chim. Acta 240, 93-98.

\section{This article should be referenced as follows:}

Karak, T., Singh, U.K., and Das, D.K. (2004) Role of various extractants in removing group-IIB elements of soils incubated with EDTA. TheScientificWorldJOURNAL 4, 1038-1045. 


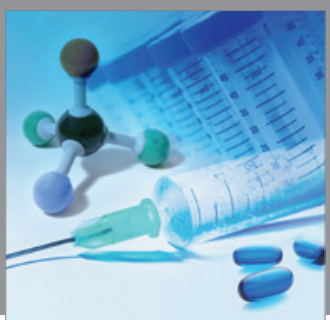

International Journal of

Medicinal Chemistry

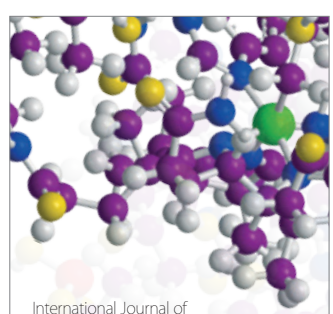

Carbohydrate Chemistry

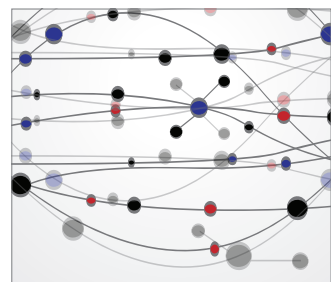

The Scientific World Journal
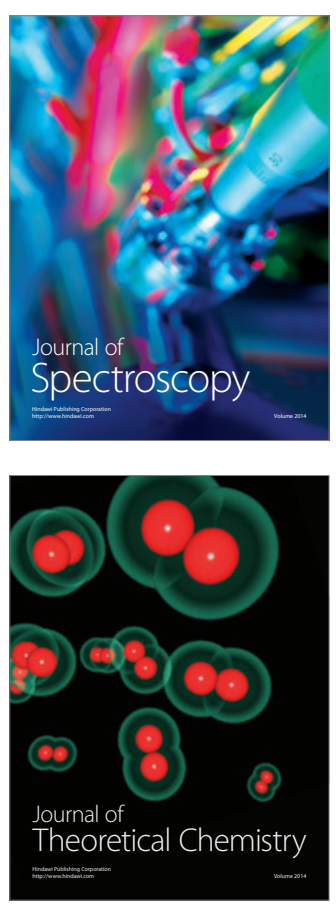
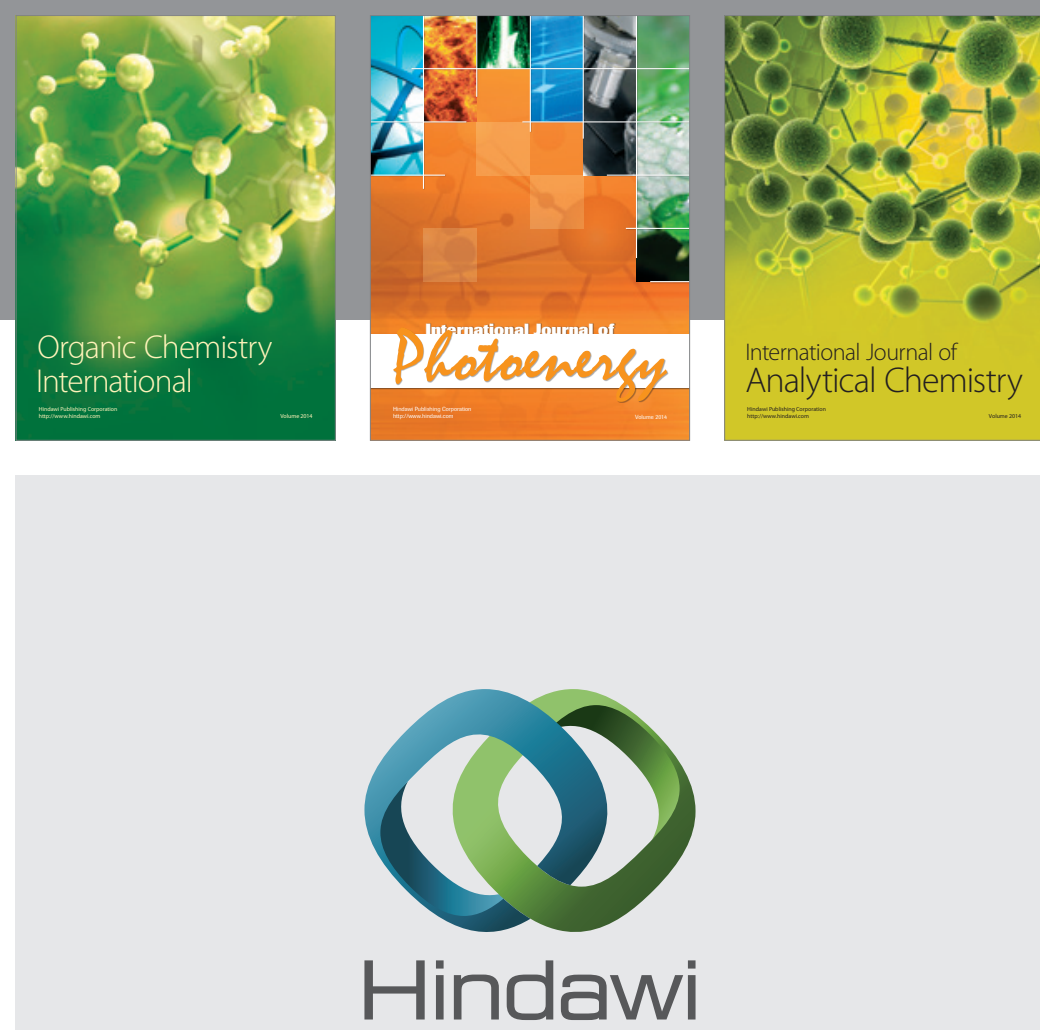

Submit your manuscripts at

http://www.hindawi.com
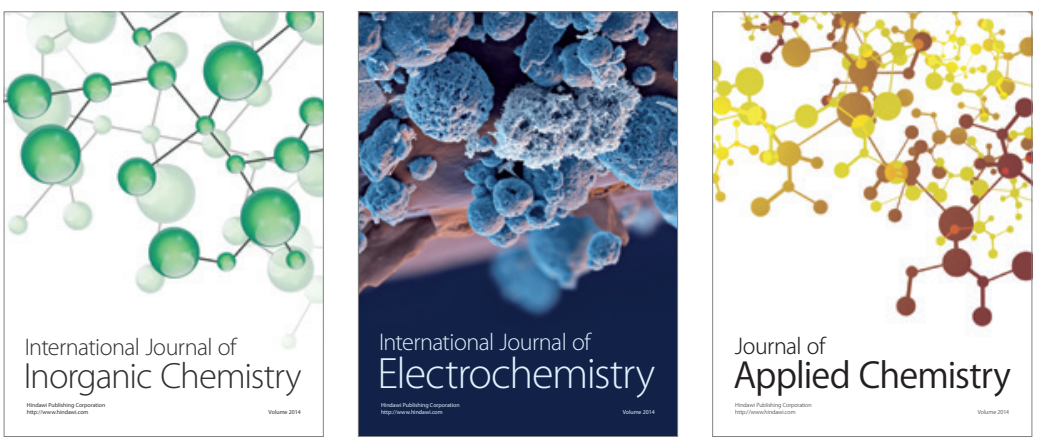

Journal of

Applied Chemistry
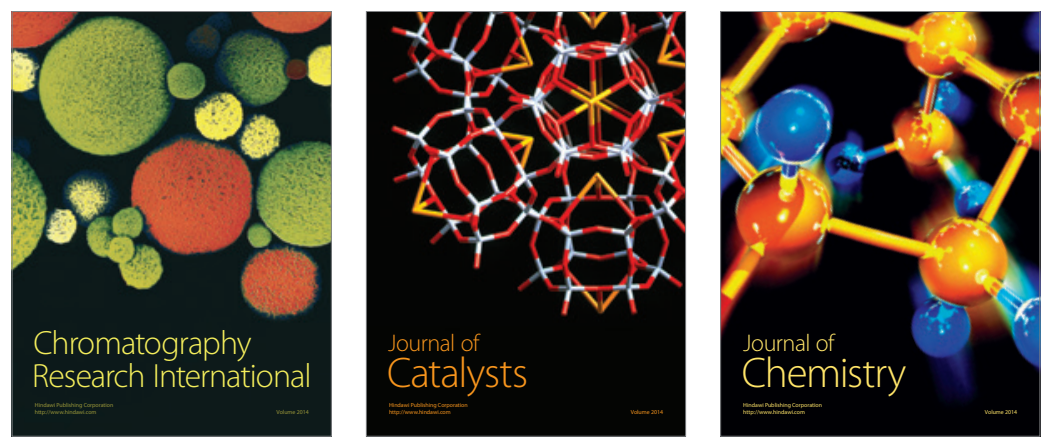
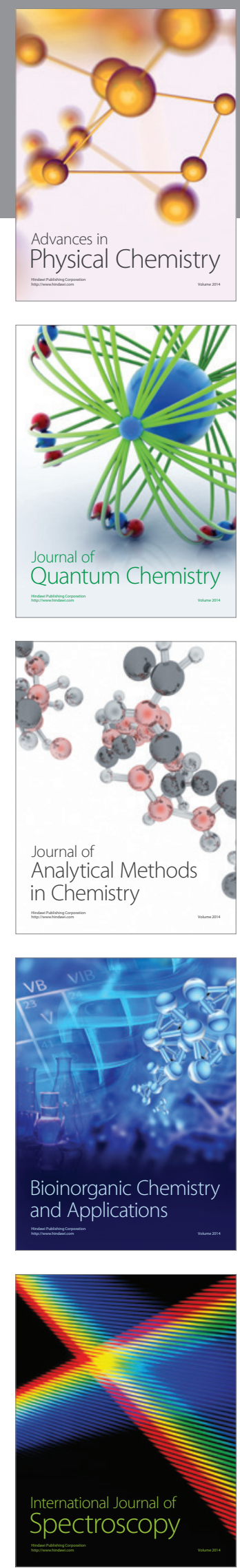